\title{
Financial Inclusion and Monetary Policy: A Review of Recent Studies
}

\author{
Abel Mawuko Agoba \\ Central University, Ghana \\ Yakubu Awudu Sare \\ University for Development Studies, Wa Campus, Ghana \\ awudusare@yahoo.com \\ and \\ Ebenezer Bugri-Anarfo \\ Ghana Institute of Management and Public Administration, Accra, Ghana \\ DOI//http://dx.doi.org/10.4314/gjds.v14i1.12
}

\begin{abstract}
This study attempts to review the extant literature on financial inclusion, financial development innovation and monetary policy. It surveys literature between 2007 and 2015 and identifies key themes in this field of study, methodologies adopted, geographical distribution of the studies and synthesises these to identify relevant gaps and direction for future research. The study makes very intetersting finding. Common areas of study can be categorised as determinants, effects and evaluation of these concepts. Areas for discussions have focused on financial inclusion and its implications for monetary policy and financial stability. The linkage between financial inclusion and monetary policy has been studied in few instances and through models that estimate a direct relationship. Studies that estimate models which examine the mediating role of financial development and innovation on the impact of financial inclusion on monetary policy are yet to be done. Researchers have mostly modeled that, growth in financial innovation, financial development and financial inclusion on their own, do individually enhance growth in total factor productivity. These studies however do not explore the possible mediating effects of these factors on another in maximising their effects. Innovation can stir up financial inclusion through the availability of various products that either transfer or mitigate the risk of providing financial services to the unbanked. However, while innovation directly spurs financial inclusion effectively, how this relationship is affected at different levels of financial development is yet to be established. Literature has documented various ways in which increased financial inclusion could be beneficial for financial stability, but it is yet to be explored how sensitive this effect could be at different levels of financial depth. These are the gaps the study identifies and recommends to be filled by furture research. The study futher recommends that empirical examination of the effect of financial development on the relationship between financial
\end{abstract}


innovation and financial inclusion be done in addition to cross-country and regional studies on the impact of financial inclusion on monetary policy using panel data.

Keywords: Financial Inclusion, Financial Development, Financial Innovation, Monetary Policy, Financial Stability

\section{Introduction}

There is currently high level activity by policy makers in pursuing financial inclusion. These studies have discussed the implications of financial exclusion for the parameters in the central bank's policy rule and model stability; the effectiveness of monetary policy and the implications for the choice of price index used as the central bank's target (Anand \& Prasad, 2012).

Financial inclusion or inclusive financing is the delivery of financial services at affordable costs to sections of disadvantaged and low-income segments of society. Financial inclusion means that individuals and businesses have access to useful and affordable financial products and services that meet their needs - transactions, payments, savings, credit and insurance - delivered in a responsible and sustainable way (World Bank, 2015). Papers which examined financial inclusion were analysed and synthesised into four sub-themes. These were policies and challenges of financial inclusion; evaluation and measurement of financial inclusion; determinants and effects. Monetary policy is the process by which the monetary authority of a country, like the central bank or currency board, controls the supply of money, often targeting an inflation rate or interest rate to ensure price stability and general trust in the currency.

The stride made by financial system toward greater economic competence is enhanced by financial innovation. Financial innovation can be defined as the act of creating and then popularising new financial instruments as well as new financial technologies, institutions and markets. It includes institutional, product and process innovation. It functions to help corporate and individual households to manage risks and this to a large extent, depends on the type of financial products or contracts available to enable them efficiently hedge and take on exposures in close alignment with their individual risk preference and tolerance. Financial innovation has also generated greater efficiency in the allocation of risks by breaking the links between origination and ownership and by creating securities that more finely allocate risks to different investor classes. The efficient discharge of this function also depends on the capability of the institutions that make up the financial system to manage the risk inherent in these products; thus the extent of financial development in the economy. This is because, imperfections within financial markets affect the performance of these innovative financial products that may in turn limit their availability (Sekhar, 2013). Financial development may be defined 
as the developments in the size, efficiency and stability of and access to the financial system. It refers to improvements in producing information about possible investments and allocating capital, monitoring firms and exerting corporate governance, trading, diversification, and management of risk, mobilization and pooling of savings, easing the exchange of goods and services. These financial functions affect savings and investment decisions, and technological innovations and hence economic growth (World Bank, 2015). Literature on financial development were identified as a key theme in this study. After further synthesis of the studies, they were identified in sub-themes namely evaluation and measurement, determinants of financial development and effects of financial development.

This has implications for financial stability as the risks that arise with innovative products have affected the financial system both at national and international level. One can therefore concede that financial inclusion, financial development, innovation and monetary policy have significant implications for financial stability. It is against this background that this paper seeks to analyse the contemporary issues and prevailing understanding on these closely influential concepts.

The findings are that in recent times, studies on financial inclusion, financial development and monetary policy mainly centre around their determinants, effects, evaluation and measurement. Most of these studies have focused mainly on crosscountry studies, were highly published in 2008 and have used mostly panel data in the analysis except for the relationship between financial inclusion and monetary policy studies which have made use of cross-sectional data. Mostly, direct relationship among these concepts have been modeled, however leaving a gap for the moderating role they play in the effect of one on the other; particularly the moderating role of financial inclusion on the effects of financial development on monetary policy and vice versa.

The specific objectives this study seeks to address include to:

i. Review and analyse extant literature on financial inclusion, financial development, innovation and monetary policy

ii. Assess, and evaluate methodologies, geographical distribution and journals publications on financial inclusion, financial development, innovation and monetary policy and

iii. Identify research gaps and prescribe directions for future research on financial inclusion, financial development and monetary policy.

The rest of the study is presented as follows: Section two focuses on the distribution of papers by key themes identified from the review. Section three reviews theories of financial inclusion, financial development, monetary policy and innovation. In section four, we present findings from the review. Section six presents a classification 
of financial inclusion; financial development, monetary policy and innovation research within the period under review and identify conceptual frameworks used in these studies. Finally, we conclude by identifying gaps and directions for future studies.

\section{Distribution of Papers by Themes}

The review consists of 130 articles. It covers the period January 2007 to 2015. This timeframe is chosen to ensure that the review captures the most current issues and debates in the field. The publications reviewed were found in the following databases: Science Direct, Emerald Full text, JSTOR, Wiley Online, Google Scholar, EBSCOhost, and Taylor and Francis. Materials reviewed include refereed and peer reviewed journals, working papers from the World Bank, IMF, and NBER which are reputed to initiate debates in current issues of importance. It identifies key themes in this field of study, methodologies adopted, geographical distribution of the studies and synthesises these to identify relevant gaps and direction for future research. Using figures and graphs, the findings of the distribution of the literature categorised on the bases of these themes are presented and discussed.

The papers reviewed were distributed across these four main themes as showed in Figure 1. Articles reviewed on monetary policy were forty thirty-one on innovation, twenty-eight on financial inclusion and thirty-three on financial development. The thin variation in the numbers point to a relatively equal interest in these themes in extant literature within the timeframe under study.

\section{Findings}

The study proceeds to present its findings and analysis on the basis of global geographic regions, research themes, theories and methodology.

\section{Distribution of Publications by Journal}

Using the Association of Business Schools (ABS) Journal Quality Guide (JQG), we find that the majority of publications are not in the top-ranked journals, though there were appreciable numbers of publications in the Journal of Baking and Finance, The Journal of International Money and Finance, and Economic Modelling, The Journal of Banking \& Journal of International Financial Markets, Institutions \& Money, Journal of Economic Studies, Journal of Monetary Economics, and World Development.

Among the top-ranked journals, the Journal of Banking and Finance (7), Journal of Policy Modelling (6), Journal of Financial Stability (6), and the Journal of Development Economics (7) had relatively higher number of publications on the above topic and related areas. This is shown in figure 2. 


\section{Distribution of Publications by Year}

Figure 3 depicts the number of articles published per year. The year 2008 recorded the highest number of publications (22). After 2008, average publications were 14. This points to the consistency and interest the topic generates in recent times.

\section{Distribution of Publications by Geographical location/distribution}

In Figure 4 the geographic distribution of articles reviewed are depicted. Most of the research were cross-country studies (59). East Asia and Pacific recorded 12 publications, Europe and Central Asia fourteen(14), Latin America and the Carribean (18), Middle East and North Africa five, North America (10), South Asia six and Sub-Saharan Africa six.

\section{Distribution of Publications by Methodology}

In figure 5, a skewed distribution of methodology adopted for the studies under review. Out of the 130 reviewed articles, 97 were quantitative, 20 were qualitative and 13 mixedmethods. The mixed-methods were mainly conceptual papers which sought to derive models; some of which were tested and others not.

\section{Classification of Financial Inclusion, Financial Development and Monetary Policy Research}

Figure 6 shows a spider diagram of the themes and sub-themes identified and synthesized from the papers reviewed. This paper proceeds to discuss them in details and shows the diagrammatic presentation.

\section{Financial Inclusion}

\section{Policies and Challenges of Financial Inclusion}

This constituted the highest number of issues studied (8) under financial inclusion. Jones (2008), Demirguc-Kunt (2008), Rosengard and Prasetyantoko (2011) and Burkett Drew (2008) examined the policies and challenges surrounding financial inclusion in Asia and Europe cross-country studies respectively. Issues examined concentrated on various governments' efforts to expand access to finance, regulatory constraints to financial inclusion in Indonesia, and the possibility for community development finance institutions to take advantage of market failures in other to improve financial inclusion. Credit unions are best placed within the financial services industry to make an impact within financially excluded communities (Jones, 2008). 


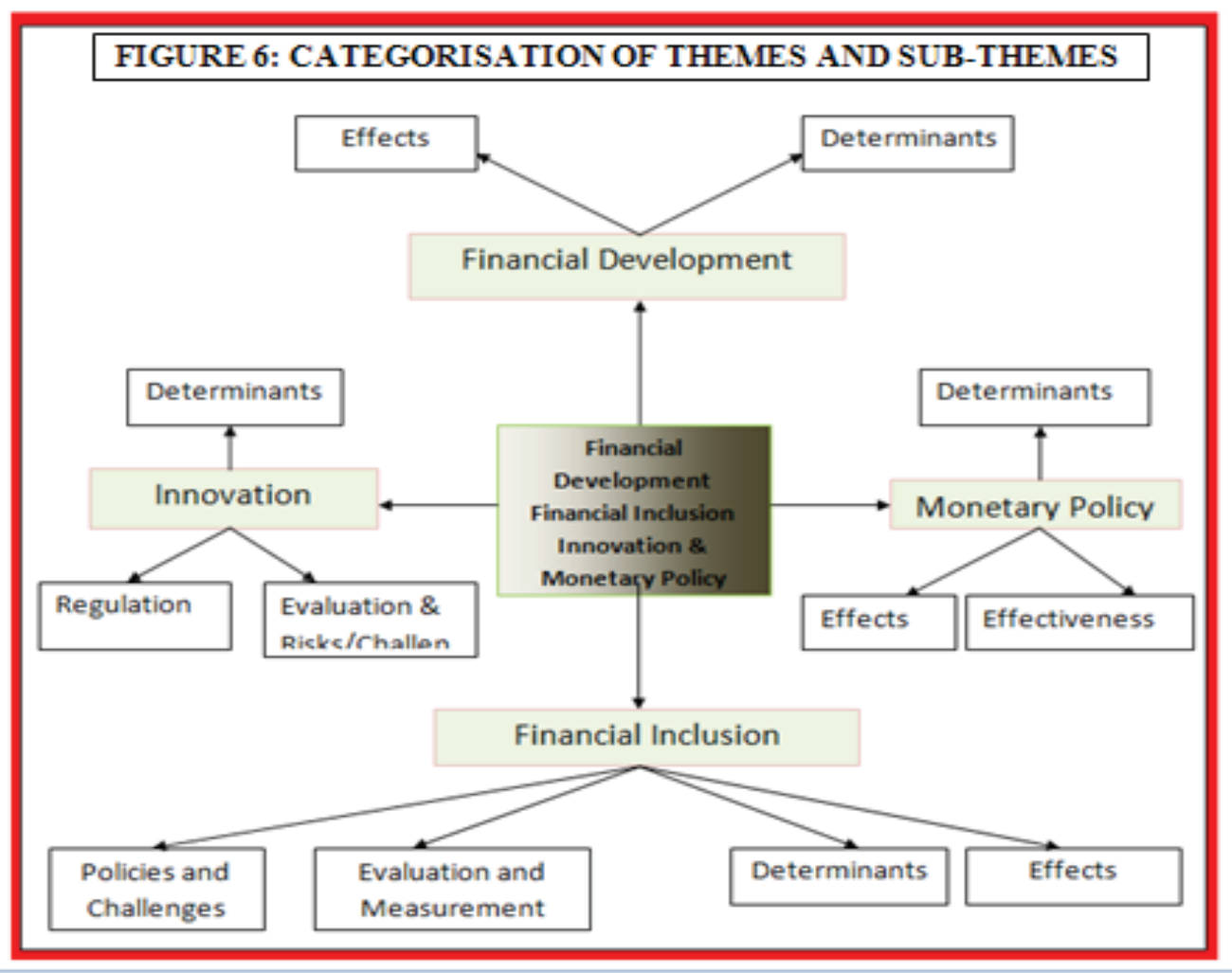

\section{Figure 6: Categorisation of themes and sub-themes}

Source: Authors, 2016

Chakraborty (2010) classified barriers to inclusion as supply side barriers (expected to be mitigated by banks) and demand side barriers (expected to be overcome by the financially excluded) (See Gupte et al., 2012).

Efforts to improve financial inclusion are hampered by factors such as high interest rates, high dropout rates from self-help groups (SHGs) and irregular repayment of loan (Chavan \& Birajor 2009). Others include identity requirements, terms and conditions of bank accounts, levels of bank charges, physical access to bank branches, psychological and cultural influences and difficulty of use of banking services (Kempson et al., 2004). There also are high bank charges, small short-term loan amounts with constant costs (Coland, 2007).

Policies aimed at improving financial inclusion are usually unbalanced with concentration on rural areas while urban areas are largely ignored, particularly among slum-dwellers (Bastia, 2010). In Bastia (2010), the use of access to savings and loans as 
a measure of financial inclusion is questioned as men had most access to loans but least number of bank accounts. This has led to studies on more appropriate measurements for financial inclusion. Improvements in human development, income, inequality, literacy, urbanisation, physical infrastructure for connectivity and information have been found to expand financial inclusion (Sarma \& Pais 2011; Dixit \& Ghosh 2013). Bester et al. (2008) considered the impact of the implementation of Anti-Money Laundering (AML) and Combating the Financing of Terrorism (CFT) controls on financial Policies that target different financial parameters have different effects on macroeconomic aggregates and are country specific (Dabla-Norris et al., 2015).

The challenges to financial inclusion seem to be homogenous across countries with high interest rates and inaccessibility to loans and accounts, cutting across. Policies aimed at improving and regulating payment systems especially mobile money and regulating it seemed to be left out in these studies.

\section{Evaluation and Measurement of Financial Inclusion}

Patrick Honohan (2007) has constructed estimates of the fraction of the households who have access to formal financial intermediaries and thereafter compared these estimates to poverty and inequality using the Gini coefficient. Honohan (2008) used the ratio of microfinance accounts and bank accounts to the total population, household survey-based access and the average deposit size and the per capita GDP for more than 160 countries. Sarma (2008 a) considered three dimensions to measure the extent of inclusion namely: 1) Depth (penetration) of access using a proxy measure of the number of bank accounts per 1000 population 2) Availability to measure proximity of access using the number of bank branches and number of ATMs per 1000 population 3) Usage to measure the extent and frequency of use by the customers.

Sarma adopted the concept used in the calculation of the Human Development Index (HDI). Sarma (2008a) has attached equal weights to the various dimensions. Depending on the value of IFI, countries are categorized as high financial inclusion (an index of above 0.6), medium financial inclusion (an index of 0.4 to 0.6 ) and low financial inclusion (an index of less than 0.4). Finally, she ranked the 45 countries (for which data on all three dimensions was available to her) and 81 countries (for which data on only two dimensions are available) in order of the IFI to indicate their relative position among other countries.

Demirguc-Kunt and Klapper (2012) developed the Global Financial Inclusion (Global Findex) database to provide such new set of indicators that measure how adults in 148 economies save, borrow, make payments, and manage risk. The main indicators on the use of formal accounts and formal credit are now collected yearly, and the full set of indicators every three years. The latest index came in 2014. Gupte et al. (2012) 
construct a Financial Inclusion Index (FII) to measure the extent of financial inclusion in India using data published by CGAP the World Bank Group in 2009 and 2010. Their computation of the Financial Inclusion Index for India, was calculated as a geometric mean of four critical dimensions - outreach (penetration and accessibility), usage, ease of transactions and cost of transactions, following the methodology used by UNDP in computing the HDI in 2010.

Amidzic et al. (2014) further provided a new composite index using factor analysis to derive a weighting methodology whose absence had been the most persistent of the criticisms of previous indices. Countries were then ranked based on the new composite index, providing an additional analytical tool which could be used for surveillance and policy purposes on a regular basis. From the above studies, we see a continual effort to measure financial inclusion better.

\section{Determinants of Financial Inclusion}

Jang et al. (2014), Allen et al. (2012), Donovan (2012), Kunt et al. (2013), Srenivasan (2015), Jones(2008) all examined the determinants of financial inclusion. This includes mobile money (Donovan, 2012); greater ownership and use of account, and policies that require banks to offer basic or low-fee accounts. Other determinants include exempting some depositors from onerous documentation requirements, allowing correspondent banking, and using bank accounts to make government payments (Allen et al., 2012). Further analysis indicate that relaxing constraints on collateral (Jang et al., 2014) improving physical infrastructure and capacity-building could lead to increased financial inclusion. (Srenivasan, 2015). Kunt et al. (2013) however found that legal discrimination against women and gender norms could account for some of the cross country variation in access to finance for women. In countries where women face legal restrictions in their ability to work, head a household, choose where to live, and receive inheritance, women were less likely to own an account, relative to men, as well as to save and borrow.

\section{Effects of Financial Inclusion}

Dittus and Klein (2007) and Manji (2010) suggest a link between access to financial services and poverty alleviation and economic development and reducing income inequalities. Subba Rao (2013) show that there has been an increase in access to credit in rural areas from informal sources. Financial inclusion contributes to local socioeconomic development but, at the same time, presents clear negative signs such as lowincome population over-indebtedness, reproduction of social exclusion practices and reinforcement of power asymmetries (Diniz et al., 2012). Mediating effects of financial inclusion on human development have been established (Unnikrishnan \& Jagannathan, 2015). Changes in financial inclusion levels is seen to affect overall human development 
directly in the high income and lower middle and lower income categories of countries. However, there is still no established relationship or correlation between human development and financial inclusion in higher middle income countries.

From Figure 7, we can observe very little has however been done on the relationship and mediating role of financial inclusion on financial development and innovation. On the effects of financial inclusion, its effect or impact on monetary policy has been scarcely investigated. This could be an interesting area of study since the inclusion of many in the financial system could enhance or negatively affect central bank's monetary policy objectives.

\section{Financial Development}

\section{Evaluation and Measurement of Financial Development}

Cihak et al., (2013) examined and compared financial development in 205 economies between 1960 and 2010. The database provided information on financial systems in 205 economies over the period from 1960 to 2010 and included measures of (1) size of financial institutions and markets (financial depth), (2) degree to which individuals and firms can and do use financial services (access), (3) efficiency of financial intermediaries and markets in intermediating resources and facilitating financial transactions (efficiency), and (4) stability of financial institutions and markets (stability).

The existing literature for the measurement of financial development comprises two different strands. The first strand of studies measure financial development as a result of the observed outcomes of financial development. These studies include size, access and depth of financial systems as a measure of financial development. The second strand includes proxies of a country's legal, business, and political conditions as well as the stability of financial^^^^ (Herger et al., 2007). Financial regulations also help to enhance the efficiency of the financial system (Herring, 1994).

\section{Determinants of Financial Development}

Following theory and substantial evidence linking financial development to economic growth (Schumpeter, 1911; King \& Levine, 1993) and poverty alleviation (Beck et al., 2007), considerable research has since focused on the factors that determine financial development. Ang and McKiban (2007), Chinn and Ito (2011) and Baltagi et al., (2009) found trade and financial openness as significant determinants of financial sector development. Do and Levchenko (2007) also find that countries with comparative advantage in financially intensive goods experience a higher demand for external finance. Gwama (2014) suggested that the traditional endowments theory does not explain financial development in African countries. 
Given the importance of financial development and the significant evidence that Africa lags behind (Beck et al., 2010; Allen et al., 2012), it is important to understand the factors that drive financial development on the continent. Past studies have explored this issue, using traditional views on mainly heterogeneous samples of industrialised and poor countries. The few studies that focus on the continent (see Allen et al., 2012) tend to dwell on historical determinants of financial development, confirming that Africa lags behind but without explaining why.

\section{Effects of Financial Development}

Hajilee and Nasser (2015) find there is a uni-directional link between FDI and banking sector development and a bi-directional link between FDI and stock market development. An increase in the budget balance also increases the current account (Chinn and Ito, 2007) and greater financial development causes higher saving. Significant directed credit programs favoring certain priority sectors tend to discourage private capital formation (Ang, 2008). Interest rate controls appear to have a positive impact on private investment while high reserve and liquidity requirements exert a positive or negative influence on private investment depending on the country. Financial development also leads to higher output growth (Ang, 2009). High rates of corruption in the Commonwealth countries are however crowding out the return to financial development (Batabyal \& Chowdhury, 2015). Ge and Qui (2007) suggest that, in a country with a poorly developed formal financial sector, firms can support their growth through non-formal financial channels that largely rely on implicit contractual relation. Financial development has also been shown to positively affect manufacturing output and agricultural growth (Raphael 2015; Khan \& Lodhi 2014). Mixed-results, however, exist for its impact on economic growth (Hassan et al., 2015; Bittencourt 2012; Kumar 2014; Nyasha \& Odhiambo 2015; Greenwood et al., 2013; Fung 2009; Ahlin and Pang 2008) in developing countries, meaning that a well-functioning financial system is a necessary but not sufficient condition to reach steady economic growth in developing countries. Yang and Yi(2008), Kai and Hamori (2009), Nazlioglu and Agir (2011), Akhter and Liu (2010), Uddin et al(2012) and Kar et al(2015) all provide evidence of the effects of financial development on economic growth

From Figure 8, the majority of papers published on financial development within the period of review centred on the effects, relationship and mediating role financial development plays in economic growth. 


\section{Financial Innovation}

\section{Determinants of Financial Innovation}

Lechman and Marszk (2015) indicate that in all countries increases in ICT penetration have relatively weak, although still positive innovation. Yuriy and Monika (2010) find that financial constraints restrain the ability of domestically owned firms to innovate and export and hence to catch up to the technological frontiers. This negative effect is amplified as financial constraints force export and innovation activities to become substitutes although they are generally natural complements. Interest rate restraints also help generate ideas (Ang, 2014).

Hsu et al., (2014) show that industries that are more dependent on external finance and that are more high-tech intensive exhibit a disproportionally higher innovation level in countries with better developed equity markets. However, the development of credit markets appears to discourage innovation in industries with these characteristics. Gorodnichenko and Schnitzer (2010) investigate theoretically and empirically how financial constraints affect a firm's innovation and export activities. They find that financial constraints restrain the ability of domestically owned firms to innovate and export and hence to catch up to the technological frontiers. This negative effect is amplified as financial constraints force export and innovation activities to become substitutes although they are generally natural complements.

\section{Risks and Challenges of Financial Innovation}

Monroy and Hernandez (2008) suggest that in the presence of challenges, there may be good chances to innovate. Hsu et al. (2013) note the risk of patent piracy in the midst of positive impact of innovation on stock returns. Ang and Kumar (2014) find cultural barriers to the diffusion of financial technology across borders negatively affecting a country's ability to adopt and adapt innovations from the frontier. Henderson and Pearson (2012) confirm that issuing firms might shroud some aspects of innovative securities or introduce complexity to exploit uninformed investors And that financial innovation also increases banks' appetite for risky investment.

The banking system becomes less stable because the portfolio risk of each individual bank increases (Kero, 2013). Technological development in Korea increased patent acquisitions (Wonglimpiyarat, 2011; Doh \& Kim 2014). Financial innovation has been found to produce increasing levels of debt (Boz \& Mendoza, 2014). Risks in innovation are better managed in teams than by individuals (Adama \& Guettler, 2015). Norden et al. (2014) also showed significant risk management benefits from financial innovations that persist under adverse conditions. 


\section{Regulation of Financial Innovation}

Kim et al. (2013) show that regulatory measures such as restrictions on bank activities and entry requirements have decreased the likelihood of a banking crisis, while capital regulation and government ownership of banks have increased the likelihood of a currency crisis. A banking crises is defined as systemic if two conditions are met: (a) significant signs of financial distress in the banking system (as indicated by significant bank runs, losses in the banking system, and or bank liquidations); and (b) significant banking policy intervention measures in response to significant losses in the banking system A currency crisis however, is a situation in which serious doubt exists as to whether a country's central bank has sufficient foreign exchange reserves to maintain the country's fixed exchange rate. The crisis is often accompanied by a speculative attack in the foreign exchange market. Financial innovation has contributed to the banking crisis but contained the currency crisis. The study also shows that judicious implementation of regulatory measures is critical to financial stability because some regulations, if implemented simultaneously, can further aggravate or alleviate a crisis. In addition to Kim et al. (2013), Awrey (2013) examined the influence of this market fundamentalist thinking on the regulation of OTC derivatives markets in the US.

\section{Relationship and Mediating Role of Financial Innovation}

Technological innovation and economic growth eventually stop unless financiers innovate (Laeven et al,. 2015; Lerner \& Tufalo, 2011). There also exists a positive relationship between eco-innovators and returns on assets and equity and lower earnings retention. Additionally, companies that introduce eco-innovation are also significantly larger, more likely to face lower financial risk exposure and more likely to possess greater free cash flow than conventional firms (Przychodzen \& Przychodzen, 2015). These suggest that strong asset and financial capabilities are relevant preconditions for the development of eco-innovativeness and that there is a need for environmental policy to create clear incentives for SMEs to increase activities in that area.

Beck et al. (2012) found that a higher level of financial innovation is associated with a stronger relationship between a country's growth opportunities and capital and GDP per capita growth and with higher growth rates in industries that rely more on external financing and depend more on innovation. They also show that financial innovation is associated with higher growth volatility among industries more dependent on external financing and on innovation and with higher idiosyncratic bank fragility, higher bank profit volatility and higher bank losses during the recent crisis. 
From figure 9, most studies on financial innovation within the period have focused on the evaluation and the risk associated with innovation as well as its effects. The least study areas are regulation and determinants of financial innovation.

\section{Monetary Policy}

\section{Determinants of Monetary Policy}

Gigineishvili (2011); Mehrotra and Yetman(2007); Leuvensteijn et al. (2008); Claeys and Vennet (2008) find that per capita GDP, inflation, competition and capital adequacy, have positive effects on interest rate pass-through, while market volatility has a negative effect. Among financial market variables exchange rate flexibility, credit quality, overhead costs, and banking competition were found to strengthen interestrate pass-through, whereas excess banking liquidity impede it. Risks may rise if greater financial inclusion results from rapid credit growth, or if relatively unregulated parts of the financial system grow quickly. Bennaceur and Goaid (2008) find that interest rate liberalization has contrasting effect on net interest margins.

Hawtrey and Liang (2008) find that national industry margins are influenced by market power, operational cost, risk aversion, interest rate volatility, credit risk, volume of loans, implicit interest payments and quality of management. Other determinants of monitory policy are high inflation, high T-Bill rates and exchange rate appreciation, communication (Blinder et al., 2008), high costs of doing business, sectoral loan portfolio composition of banks Beck and Hesse (2009), liquidity, capitalization and relationship lending (Gambacorta (2008) in the short run.

\section{Effects of Monetary Policy}

Abiad et al. (2008) introduced a new database of financial reforms, covering 91 economies over 1973-2005. The database provides a multi-faceted measure of reform, covering seven aspects of financial sector policy. Granville and Mallick (2009) show that interest rate instrument used for inflation targeting is conducive to financial stability. Giorgio and Rotondi (2011) examines the interaction between monetary policy and financial stability and provides an assessment of the implications of banks' risk management practices for monetary policy. They find that the practice of smoothing interest rates backward does not in general alleviate problems of equilibrium indeterminacy.

Hannig and Jasen (2010) argued that greater financial inclusion presents opportunities to enhance financial stability as financial inclusion poses risks at the institutional level. Mbutor and Uba's (2015) study supports the notion that growing financial inclusion would improve the effectiveness of monetary policy. Borio and Zhu (2008) argue that changes in the financial system and prudential regulation may have increased the 
importance of the risk-taking channel .There therefore appears to $\wedge^{\wedge \wedge}$ mixed results and arguments on the implication of inclusive growth and regulation on monetary policy success or risks. Graeve et al. (2008) results confirm the existence of a trade-off between monetary and financial stability. Governments will however need to act more systemically, addressing issues in market information and market structure and on the demand side and ultimately supporting a deeper level of financial sector reform (Miller, 2009).

\section{Effectiveness of Monetary Policy}

Aastveit et al. (2008) find that monetary policy shocks affect economic activity considerably weaker when uncertainty is high, consistently with "real-options" effects suggested by models with non-convex adjustment costs. Mehrotra and Yetman (2014) find evidence that where financial inclusion is low, central bank rate moves have to be larger in order to stabilise the economy after a shock. They also find evidence that the greater the level of financial inclusion, the more central banks are able to stabilise inflation without affecting economic activity. Mehrotra and Yetman (2015) outlined various ways in which increasing financial inclusion affects central bank policies intended to maintain monetary and financial stability. They note that, increased financial inclusion facilitates consumption smoothing, as households have easier access to instruments for saving and borrowing.

In Figure 10, most studies on monetary policy have focused on the determinants. There is still a wide research gap on the relationship it has with financial inclusion, innovation and financial development.

\section{Conclusion and Recommendations for Future Research}

In our review of the discussions on financial inclusion, financial development, financial innovation and monetary policy, we first of all realise common areas of study such as the determinants, effects and evaluation of these concepts. Findings have been both homogenous and heterogeneous with few contrary results. In the most recent times, interesting areas for discussions have focused on financial inclusion and its implications for monetary policy and financial stability. With discussions still hovering on the most appropriate way to capture financial inclusion variables in an index, and the increasing availability of data over time, further studies using panel data should improve upon the findings already gathered.

Secondly, studies on the effectiveness of policies implemented so far and the success of the removal of regulatory constraints or improvements in regulation in individual countries would throw more light on the best way forward for government policies on financial inclusion. The review of extant literature shows that, researchers have mostly 
modeled that, growth in financial innovation, financial development and financial inclusion on their own, do individually enhance growth in total factor productivity. These studies however do not explore the possible mediating effects of these factors on another in maximising their effects. It is subsequently, recommended that empirical examination of the effect of financial development on the relationship between financial innovation and financial inclusion be done. Innovation can stir up financial inclusion through the availability of various products that either transfer or mitigate the risk of providing financial services to the unbanked. However, while innovation alone spurs financial inclusion effectively, how innovation affects financial inclusion at different levels of financial development is yet to be established. This is another area recommended for further studies. Also, though literature has documented various ways in which increased financial inclusion could be beneficial for financial stability, it is yet to be explored how sensitive this effect could be at different levels of financial depth. The study therefore recommends future studies that examine the intermediating role of financial depth on the effect of financial inclusion on financial stability.

\section{References}

Aastveit, K. A., Natvik, G. J. and Sola, S. (2013). Economic uncertainty and the effectiveness of monetary policy. Norges Bank Working Paper 17.

Abiad, A., Detragiache, E. and Tressel, T. (2008). A new database of financial reforms: International Monetary Fund.

Abiad, A., Oomes, N. and Ueda, K. (2008). The quality effect: Does financial liberalization improve the allocation of capital? Journal of Development Economics, $87(2)$, pp. $270-282$.

Acemoglu, D. and Cao, D. (2015). Innovation by entrants and incumbents. Journal of Economic Theory, 157(o), pp. 255-294.

Adam, T. and Guettler, A. (2015). Pitfalls and perils of financial innovation: The use of CDS by corporate bond funds. Journal of Banking \& Finance, 55(o), pp. 204-214.

Adnan, N. (2009). Measurement of Financial Development: A Fresh Approach. 8th International Conference on Islamic Economics and Finance.

Adu, G., Marbuah, G. and Mensah, J.T. (2013). Financial Development and economic growth in Ghana: Does the measure of financial development matter? Review of Development Finance, 3, pp.192-203.

Ahlin, C. and Pang, J. (2008). Are financial development and corruption control substitutes in promoting growth? Journal of Development Economics, 86(2), pp. 414433 . 
Akhter, S., and Daly, K. J. (2009). Finance and poverty: Evidence from fixed effect vector decomposition. Emerging Markets Review, 10(3), pp. 191-206.

Akhter, S., Liu, Y., and Daly, K. (2009). Cross country evidence on the linkages between financial development and poverty. International Journal of Business and Management, 5(1), pp. 1-3

Allen, F., Demirgüç-Kunt, A., Klapper, L. F., and Martinez Peria, M. S. (2012). The foundations of financial inclusion: Understanding ownership and use of formal accounts. World Bank Policy Research Working Paper (6290).

Amidzic, G., Massara, A. and Mialou A., (2014). Assessing Countries Financial Inclusion Standing a New Composite Index. IMF Working Paper, Wp/14/36.

Anand, R. and E. S., Prasad (2012). Core versus headline inflation targeting in models with incomplete markets, manuscript.

Ang, J. B. (2008). What are the mechanisms linking financial development and economic growth in Malaysia? Economic Modelling, 25(1), p. 38.

Ang, J. B. (2009). Private Investment and Financial Sector Policies in India and Malaysia. World Development, 37(7), p.1261.

Ang, J. B. (2014). Innovation and financial liberalization. Journal of Banking \& Finance, 47(0), p. 214.

Ang, J. B. and Kumar, S. (2014). Financial development and barriers to the cross-border diffusion of financial innovation. Journal of Banking \& Finance, 39(o), pp. 43-56.

Ang, J. B. and McKibbin, W. J. (2007). Financial liberalization, financial sector development and growth: evidence from Malaysia. Journal of Development Economics, 84(1), pp. 215-233.

Antzoulatos, A. A., Tsoumac, C. and Kyriazis, D. (2008). Financial Development and Assymetric Information. Available at SSRN:http://ssrn.co/abstract=11000032.

Arestis, P. and Mihailov. A. (2011). Classifying monetary economics: fields and methods from past to future. Journal of Economics Survey, 25(4), pp. 769-8oo.

Baltagi B.H., Demetriades P.O. and Law S.H. (2009). Financial development and openness: Evidence from panel data. Journal of Development Economics, 89, pp. 285296

Batabyal, S. and Chowdhury, A., 2015. Curbing corruption, financial development and income inequality. Progress in Development Studies, 15(1), pp. 49-72.

Beck, T. and Hesse, H. (2009). Why are interest spreads so high in Uganda? Journal of Development Economics, 88(2), pp. 192-204. 
Beck, T., A. Demirgüç-Kunt and O. Merrouche (2013). Islamic Vs. Conventional Banking: Business Model, Efficiency and Stability. Journal of Banking and Finance, Vol. 37, Issue, pp. 33-447.

Beck, T., Chen, T., Lin, C. and Song, F. M. (2016). Financial innovation: The bright and the dark sides. Journal of Banking \& Finance, 72, pp. 28-51.

Beck, T., Demirgüç-Kunt, A. and Levine, R. (2007). Finance, Inequality and the Poor, Journal of Economic Growth 12(1), pp. 27-49.

Beck, T., Demirgüç-Kunt, A. and Levine, R. (2010). Financial institutions and markets across countries and over time: The updated financial development and structure database. The World Bank Economic Review, 24(1), pp.77-92.

Bennaceur, S. and Goaid, M. (2008). The Determinants of Commercial Bank Interest Margin and Profitability: Evidence from Tunisia - Frontiers in Finance and Economics - Vol.5 No1-April 2008, pp. 106 - 130.

Bester, H., Chamberlain, D., De Koker, L., Hougaard, C., Short, R., Smith, A. and Walker, R. (2008). Implementing FATF standards in developing countries and financial inclusion: Findings and guidelines (Doctoral dissertation, FIRST Initiative (World Bank)).

Bilbiie, F. (2008). Limited asset market participation, monetary policy and (inverted) aggregate demand logic, Journal of Economic Theory, Vol. 140(1), pp. 62-96.

Bittencourt, M. (2012). Financial development and economic growth in Latin America: Is Schumpeter right? Journal of Policy Modeling, 34(3), pp. 341-355.

Blinder, A. S., Ehrmann, M., Fratzscher, M., De Haan, J. and Jansen, D. J. (2008). Central bank communication and monetary policy: A survey of theory and evidence: National Bureau of Economic Research.

Borio, C. and zhu, H. (2012). Capital regulation, risk-taking and monetary policy: a missing link in the transmission mechanism? Journal of Financial Stability, 8(4), 236-251.

Boz, E. and Mendoza, E. G. (2014). Financial innovation, the discovery of risk, and the U.S. credit crisis. Journal of Monetary Economics, 62(o), pp.1-22.

Bulmer-Thomas, V. (2003). The economic history of Latin America since independence. Cambridge University Press. Cambridge, UK.

Burkett, I. and Drew, B. (2008). Financial Inclusion, market failures and new markets: Possibilities for Community Development: Brisbane: Foresters Community Finance

Chadha J.S., Corrado G. and Corrado L. (2013), Stabilisation policy in a model of consumption, housing collateral and bank lending. Studies in Economics 1316, School of Economics, University of Kent. 
Chakraborty, I. (2010). Financial development and economic growth in India: An analysis of the post-reform period. South Asia Economic Journal, 11(2), pp. 287-308.

Kumar, C. and Mishra, S. (2009, ). Banking Outreach and Household level Access: Analysing Financial Inclusion in India. 13th Annual Conference on Money and Finance in the Indian Economy. 25-26th February, 2011.

Chavan, P. and Birajdar, B. (2009). Micro finance and financial inclusion of women: An evaluation. Reserve Bank of India Occasional Papers, 30(2), pp. 109-129.

Chinn, M. D. and Ito, H. (2007). Current account balances, financial development and institutions: Assaying the world "saving glut". Journal of International Money and Finance, 26(4), pp. 546-569.

Chinn, M. D. and Ito, H. (2011). What matters for financial development? Capital controls, institutions and interactions. Journal of Development Economics, 81, pp. 163-192.

Čihák, M., Demirgüč-Kunt, A., Feyen, E. and Levine, R. (2013). Financial development in 205 economies, 1960 to 2010 (No. w18946). National Bureau of Economic Research.

Claeys, S. and Vennet, R.V. (2008). Determinants of bank interest margins in Central and Eastern Europe: A comparison with the West . Economic Systems 32, pp. 197-216

Colciago, A. (2011). Rule-of-thumb consumers meet sticky wages. Journal of Money, Credit and Banking, Vol. 43(2-3), pp. 25-53.

Collard, S. (2007). Toward financial inclusion in the UK: Progress and challenges. Public Money and Management, 27:1, pp. 13-20.

Dabla-Norris E., Townsend Y.J.I. and Unsal D.F. (2015). Identifying constraints to financial inclusion and their impact on and inequality: a structural framework for policy.imf working paper

Demirgüç-Kunt and Levine, R. (2009). Finance and inequality: Theory and evidence, Annual Review of Financial Economics 1, pp. 287-318.

Demirgüç-Kunt, A., and Klapper, L. F. (2012). Measuring financial inclusion: The global FINDEX database. World Bank Policy Research Working Paper (6025).

Demirguc-Kunt, A., Beck, T. and Honohan, P. (2008). Finance for all. Policies and Pitfalls in Expanding Access. World Bank.

Diamond D.W. (1984). Financial intermediation and monitoring. Review of Economic Studies. 51, pp. 393-414.

Diniz, E., Birochi, R. and Pozzebon, M. (2012). Triggers and barriers to financial inclusion: The use of ICT-based branchless banking in an Amazon county. Electronic Commerce Research and Applications, 11(5), pp. 484-494. 
Klein, M. and Dittus, P. (2011). On harnessing the potential of financial inclusion. Bank of International Settlements.

Dixit, R. and Ghosh, M. (2013). Financial inclusion for inclusive growth of India-a study of Indian states. International Journal of Business Management \& Research, 3(1), pp. 147-156.

Di Bartolomeo, G and L Rossi (2007). Effectiveness of monetary policy and limited asset market participation: Neoclassical versus Keynesian effects, International Journal of Economic Theory 3(3), pp. 213-218.

Do, Q. T. and Levchenko, A. A. (2007). Comparative advantage, demand for external finance, and financial development. Journal of Financial Economics, 86(3), pp. 796834

Doh, S. and Kim, B. (2014). Government support for SME innovations in the regional industries: The case of government financial support programme in South Korea. Research Policy, 43(9), pp. 1557-1569.

Donovan, K. P. (2012). Mobile money, more freedom? The impact of M-PESA's network power on development as freedom. International Journal of Communication, 6, pp. 23.

Easterly, W. (2006). The Big-Push Déjà vu. Journal of Economic Literature. Vol. 44. No.1.

Fung, M. K. (2009). Financial development and economic growth: Convergence or divergence? Journal of International Money and Finance, 28(1), pp. 56-67.

Galí, J., J. López-Salido and J. Vallés (2004). Rule-of-thumb consumers and the design of interest rate rules, Journal of Money, Credit and Banking, Vol. 36(4), pp. 739-63.

Gambacorta, L. (2008). How do banks set interest rates? European Economic Review, 52(5), pp. 792-819.

Ge, Y. and Qiu, J. (2007). Financial development, bank discrimination and trade credit. Journal of Banking \& Finance, 31(2), pp. 513-530.

Gigineishvili, M. N. (2011). Determinants of interest rate pass-through: Do macroeconomic conditions and financial market structure matter? (No. 11-176). International Monetary Fund.

Di Giorgio, G. and Rotondi, z. (2011). Financial stability, interest-rate smoothing and equilibrium determinacy. Journal of Financial Stability, 7(1), pp. 1-9.

De Graeve, D., Kick, T. and Koetter M. (2008). Monetary policy and financial (in) stability: An integrated micro-macro approach. Journal of Financial Stability 4, pp. 205-23. 
Granville, B. and Mallick, S. (2009). Monetary and financial stability in the euro area: Pro-cyclicality versus trade-off. Journal of International Financial Markets, Institutions and Money, 19(4), pp. 662-674.

Greenwood, J., Sanchez, J. M. and Wang, C. (2013). Quantifying the impact of financial development on economic development. Review of Economic Dynamics, 16(1), 194215 .

Gupte, R., Venkataramani, B. and Gupta, D. (2012). Computation of financial inclusion index for India. Procedia-Social and Behavioral Sciences, 37, pp. 133-149.

Hajilee, M. and Al-Nasser, O.M. (2015). The relationship between financial market development and foreign direct investment in Latin American countries. The Journal of Developing Areas, 49(2).

Hassan, M. K., Sanchez, B. and Yu, J.-S. (2011). Financial development and economic growth: New evidence from panel data. The Quarterly Review of Economics and Finance, 51(1), pp. 88-104.

Hawtrey, K. and Liang, H. (2008). Bank interest margins in OECD countries. North American Journal of Economics and Finance 19, pp. 249-260.

Henderson, B. J. and Pearson, N. D. (2011). The dark side of financial innovation: A case study of the pricing of a retail financial product. Journal of Financial Economics, 100(2), pp. 227-247.

Herger, N. Holder, R. and Lobsiger M. (2007). What determines Financial Development? Culture, Institutions, or Trade, NCCR Trade Working Paper No. 05.

Herring, R. J. and Litan, R. E. (1994). Financial regulation in the global economy. Brookings Institution Press.

Honohan, P. (2008). Cross-country variation in household access to financial services. Journal of Banking and Finance, 32(11), pp. 2493-2500.

Hsu, P.-H., Tian, X., and Xu, Y. (2014). Financial development and innovation: Crosscountry evidence. Journal of Financial Economics, 112 (1), pp. 116-135.

Hsu, P. H., Wang, C. and Wu, C. (2013). Banking systems, innovations, intellectual property protections, and financial markets: Evidence from China. Journal of Business Research, 66(12), 2390-2396.

Jang, B.Y., Benicio D. and Chiyaba G. (2014). Enhancing Financial Inclusion in Zambia. IMF Working Papers.

Jones, P. A. (2008). From tackling poverty to achieving financial inclusion-The changing role of British credit unions in low income communities. The Journal of Socio-Economics, 37(6), pp. 2141-2154. 
Kai, H. and Hamori, S. (2009). Globalization, financial depth and inequality in SubSaharan Africa. Economics Bulletin, 29(3), pp. 2025-2037.

Kar, M., Agir, H. and Peker, O. (2011). Financial development and poverty reduction in Turkey. Department of Economics, Adana, Çukurova University, Turkey.

Kar, M., Nazlıŏlu, ş. and Ağır, H. (2011). Financial development and economic growth nexus in the MENA countries: Bootstrap panel granger causality analysis. Economic Modelling, 28(1-2), pp. 685-693.

Kempson E., Whyley C. (1999). Kept Out or Opted Out? Policy Press: Bristol.

Kempson, E., Atkinson, A. and Pilley, 0. (2004). Policy level response to financial exclusion in developed economies: lessons for developing countries. Report of Personal Finance Research Centre, University of Bristol.

Kero, A. (2013). Banks' risk taking, financial innovation and macroeconomic risk. The Quarterly Review of Economics and Finance, 53(2), pp. 112-124.

Khan, M.Z. and Lodhi, A. S. (2014) Nexus between Financial Development, Agriculture Raw Material Exports, Trade Openness and Economic Growth of Pakistan. Pakistan Journal of Commerce and Social Sciences.2014, Vol. 8 (3), pp. 629-639.

Kim, T., Koo, B. and Park, M. (2013). Role of financial regulation and innovation in the financial crisis. Journal of Financial Stability, 9(4), pp. 662-672.

Kumar, S. (2014). Financial Development as an Instrument of Economic Growth in India: Evidence from Co-integration and Causality Analysis. IUP Journal of Applied Economics, 13(4), p. 28.

Laeven, L., Levine, R. and Michalopoulos, S. (2015). Financial innovation and endogenous growth. Journal of Financial Intermediation, 24(1), pp. 1-24.

La Ports, R., Lopez-de-Silane, F., Shleifer A. and Vishny, R.W. (1997). Legal Determinants of External Finne. Journal of Finance, 52, pp. 1131-1150.

Lerner, J. and Tufano, P. (2011). The consequences of financial innovation: a counterfactual research agenda. Annual. Review of Financial Economics, 3(1), pp. 4185 .

French, S., Leyshon, A. and Meek, s. (2013). The changing geography of British bank and building society branch networks, 2003-2012.

Leyshon, A. and Thrift, N. (1993). The restructuring of the UK financial services industry in the 1990s: A reversal of fortune? Journal of Rural Studies, 9, pp. 223-241.

Leyshon, A. and Thrift, N. (1995), Geographies of financial exclusion: financial abandonment in Britain and the United States. Transactions of the Institute of British Geographers, New Series, 20, pp. 312-341. 
Liu, S. T. (2011). Performance measurement of Taiwan financial holding companies: An additive efficiency decomposition approach. Expert Systems with Applications, 38(5), 5674-5679.

Mahendra, S.D. (2006). Financial Inclusion: Issues and Challenges. Economic Political Weekly 41(41), pp. 4310-4313.

Mehrotra, A.N. and Yetman, J. (2015). Financial Inclusion-Issues for central banks. BIS Quarterly Review, pp. 43-57.

Mehrotra. A.N. and Yetman, J. (2014). Financial Inclusion and optimal monetary policy. BIS Quarterly Review, pp. 40-45.

Mehrotra, N., Puhazhendhi, V., Nair G. and Sahoo, B. B. (2009). Financial inclusion - An Overview. Department of Economic Analysis and Research, National Bank for Agriculture and Rural Development (NABARD), Occasional Paper 48, Mumbai.

Manji, A. (2010). Eliminating poverty? 'Financial inclusion', access to land, and gender equality in international development. The Modern Law Review, 73(6), pp. 985-1004.

Markowitz, H. M. (1959).Portfolio selection: Efficient Diversification of Investments, Yale University Press, Wiley.

Mbutor, M.O. and Uba I. A. (2013). The impact of financial inclusion on monetary policy in Nigeria. Journal of Economics and International Finance. Vol. 5(8), pp. 318-326.

McKinnon, R. I. (1973). Money and Capital in economic development. Brookings Institutions Press. Washington, DC).

Miller, H. (2013). Interest rate caps and their impact on financial inclusion. Economic and Private Sector, Professional Evidence and Applied Knowledge Services.

Mishkin, F. S. (2009). Globalization and financial development. Journal of Development Economics, 89(2), pp. 164-169.

Modigliani and Miller, M. H. (1958). The cost of capital, corporation finance and the theory of investment. The American Economic Review, pp. 261-297

Monroy, C. R. and Hernandez, A. S. S. (2008). Strengthening financial innovation in energy supply projects for rural exploitations in developing countries. Renewable and Sustainable Energy Reviews, 12(7), pp.1928-1943.

Nazlioglu and Agir (2011). Financial development and economic growth nexus in the MENA countries: Bootstrap panel granger causality analysis. Economic Modelling 28, pp. 685-693

Ndebbio, J. (2004). Financial deepening, economic growth and development: evidence from selected sub-saharan Africa countries, AERC research paper 142, Nairobi: AERC 
Norden, L., Silva Buston, C. and Wagner, W. (2014). Financial innovation and bank behavior: Evidence from credit markets. Journal of Economic Dynamics and Control, 43(o), pp. 130-145.

Nyasha, S. and Odhiambo, N.M. (2015). The Impact of banks and stock market development on economic growth in South Africa: an ARDL-bounds Testing Approach. Contemporary Economics. Vol. 9, Issue 1, pp. 93-108.

Honohan P. (2008). Cross-Country variation in household access to financial services. Journal of Banking and Finance. 32. may.2493-2500.

Przychodzen, J. and Przychodzen, W. (2015). Relationships between eco-innovation and financial performance - evidence from publicly traded companies in Poland and Hungary. Journal of Cleaner Production, 9o(o), pp. 253-263.

Rajan, R.G., Zingales, L. (2003). The great reversals: the politics of financial development in the twentieth century. Journal of Financial Economics. 69, pp. 5-50.

Raphael, A.I. and Gabriel A. A. (2015). Effect of Financial Sector Development on Manufacturing Output Growth in Nigeria (1986-2012): A Vector Auto Regression Approach. Journal of Applied Economics and Business Research. 5(1), pp. 38-55

Rosengard, J. K. and Prasetyantoko, A. (2011). If the banks are doing so well, why can't I get a loan? Regulatory constraints to financial inclusion in Indonesia. Asian Economic Policy Review, 6(2), pp.273-296.

Saci, K. and Holden, K. (2008). Evidence on growth and financial development using principal components. Applied Financial Economics, 18(190), pp. 1549-1560

Sarkar, P. and Singh, A. (2010). Law, finance and development: further analyses of longitudinal data. Cambridge Journal of Economics, Oxford University Press, Vol. 34(2), pp. 325-346.

Sarma, M. (2008). Index of financial inclusion. Indian Council for Research on International Economics Relations.

Sarma, M. (2012). Index of Financial Inclusion - A measure of financial sector inclusiveness. Berlin Working Papers on Money, Finance, Trade and Development. July, 2012. 1-34.

Sarma, M. and Pais, J. (2011). Financial inclusion and development. Journal of International Development, 23(5), pp. 613-628.

Schumpeter, J. (1911). The theory of economic development. Cambridge: Harvard University Press.

Schumpeter, J. (1943). Capitalism, Socialism, and Democracy, New York: Harvard University Press. 
Sekhar, G.V. (2013). Theorems and theories of financial Innovation: Models and mechanism perspective. Financial and Quantitative Analysis. 1(2), pp. 26-29.

Shaw E. (1973). Financial Deepening in Economic Development. Brookings, Washington, DC

Srinivasan, N. (2007). Policy issues and role of banking system in financial inclusion. Economic and Political Weekly, pp. 3091-3095.

Subba Roa. K. G. K. (2007). Financial inclusion: An introspection. Economic and Political Weekly, Vol. 42, No. 5 (Feb. 3-9, 2007), pp. 355-36o.

Uddin, G. S., Kyophilavong, P. and Sydee, N. (2012). The casual nexus of banking sector development and poverty reduction. International Journal of Economics and Financial Issues, 2(3), 304-311.

Uddin, G. S., Shahbaz, M., Arouri, M. and Teulon, F. (2014). Financial development and poverty reduction nexus: A cointegration and causality analysis in Bangladesh. Economic Modelling, 36, pp. 405-412.

Unnikrishnan, R. and Jagannathan, L. (2015). Unearthing global financial inclusion levels and analysis of financial inclusion as a mediating factor in global human development. Serbian Journal of Management 10 (1), pp. 19 - 32.

Van Leuvensteijn, M., Kok Sørensen, C., Bikker, J.A. and Van Rixtel, A.A.R.J.M. (2008). Impact of Bank Competition on the Interest Rate Pass-through in the Euro Area. DNB Working Paper nr 171, De Nederlandsche Bank, Amsterdam/ECB Working Paper nr 885, European Central Bank, Frankfurt.

Wonglimpiyarat, J. (2011). The dynamics of financial innovation system. The Journal of High Technology Management Research, 22(1), pp. 36-46.

Yang, Y. Y. and Yi, M. H. (2008). Does financial development cause economic growth? Implication for policy in Korea. Journal of Policy Modeling, 30(5), pp. 827-840.

Yuriy G. and Monika S. (2010). Financial constraints and innovation: why poor countries don't catch up. Discussion Paper No. 4786 February 2010. The Institute for the Study of Labor (IZA). 